$\begin{array}{ll}\text { Jarosław MARCISZ } & \text { (i) } 0000-0002-0001-2197 \\ \text { Artur ŻAK } & \text { (iD) } 0000-0002-1902-8615 \\ \text { Jerzy STĘPIEŃ } & \text { (iD) } 0000-0002-1702-424 X \\ \text { Marek BURDEK } & \text { (iD) } 0000-0002-2556-6460 \\ \text { Tymoteusz TOMCZAK } & \text { (iD) } 0000-0001-8339-7792\end{array}$

Sieć Badawcza Łukasiewicz - Instytut Metalurgii Żelaza — Łukasiewicz Research Network - Institute of Ferrous Metallurgy

Wojciech BURIAN $\quad$ (iD) 0000-0002-2759-2929

Sieć Badawcza Łukasiewicz - Instytut Metali Nieżelaznych — Łukasiewicz Research Network - Institute of Non-Ferrous Metals

Jacek JANISZEWSKI

0000-0003-3783-8774

Wojskowa Akademia Techniczna, Wydział Mechatroniki Uzbrojenia i Lotnictwa

Military University of Technology, Faculty of Mechatronics, Armament and Aerospace

Mateusz PYTLIK $\quad$ (D) 0000-0001-6659-2406

Główny Instytut Górnictwa $\square$ Central Mining Institute

\title{
MICROSTRUCTURE AND MECHANICAL PROPERTIES OF STEELS FOR SHAPED CHARGE LINERS AND PRELIMINARY ASSESSMENT OF THE EFFECTIVENESS OF EXPERIMENTAL SHAPED CHARGES INTENDED FOR USE IN THE MINING INDUSTRY
}

\author{
MIKROSTRUKTURA I WŁAŚCIWOŚCI MECHANICZNE STALI PRZEZNACZONYCH \\ DO WYTWARZANIA WKEADEK KUMULACYJNYCH ORAZ WSTĘPNA OCENA \\ SKUTECZNOŚCI ŁADUNKÓW EKSPERYMENTALNYCH PRZEZNACZONYCH \\ DO ZASTOSOWANIA W PRZEMYŚLE WYDOBYWCZYM
}

\begin{abstract}
The paper presents the results of investigation of the microstructure and mechanical properties of Fe-based materials designed for the manufacture of semi-spherical liners for experimental shaped charges. The tests were carried out on material samples taken from two semi-finished products, i.e. a rod for the manufacture of charge liners with a diameter of $50 \mathrm{~mm}$ using machining, and sheets for the manufacture of liners with a diameter of $100 \mathrm{~mm}$ using cold drawing. Microstructure examination was also carried out on a test specimen obtained using the additive method (3D-WAAM), made of low-carbon unalloyed steel wire. Firing tests on concrete blocks were carried out in order to quantify the effects of drilling at the Experimental Mine Barbara. The scope of the tests consisted of firing at cylindrical concrete blocks using projectiles containing $50 \mathrm{~mm}$ diameter liners made of Fe-based alloys. Based on the results of the laboratory material, two experimental steel grades were selected for further testing. Plates made of the selected steels will be used to manufacture charge liners with a diameter of $100 \mathrm{~mm}$.
\end{abstract}

Keywords: shaped charge liners, Fe-based alloys, microstructure, mechanical properties, rock drilling
Przedstawiono wyniki badań mikrostruktury $i$ wtaściwości mechanicznych materiatów na bazie Fe przeznaczonych do wytwarzania wkładek pótsferycznych do eksperymentalnych tadunków kumulacyjnych. Badaniom poddano próbki materiałowe pobrane $z$ dwóch pótfabrykatów, tj. pręta do wytwarzania wkładek kumulacyjnych o średnicy $50 \mathrm{~mm}$ metoda obróbki skrawaniem oraz blach do wytwarzania wkładek o średnicy $100 \mathrm{~mm}$ metoda tłoczenia na zimno. Przeprowadzono badania mikrostruktury próbki testowej wykonanej metoda przyrostowa (3D-WAAM) z drutu ze stali niskowęlowej niestopowej. Próby strzelania do bloków betonowych $w$ celu ilościowego oszacowania skutków drązenia otworów przeprowadzono w Kopalni Doświadczalnej Barbara. Zakres badań obejmowat strzelanie do walcowych bloków betonowych z wykorzystaniem pocisków zawierajacych wkładki o średnicy $50 \mathrm{~mm}$ wykonane ze stopów na bazie Fe. Na podstawie wyników badań materiatu laboratoryjnego wytypowano do dalszych badan dwa eksperymentalne gatunki stali. Blachy z dobranych stali będa wykorzystane do wytwarzania wkładek kumulacyjnych o średnicy $100 \mathrm{~mm}$.

Stowa kluczowe: wkładki do pocisków kumulacyjnych, stopy na bazie Fe, mikrostruktura, wtaściwości mechaniczne, drażenie skat 


\section{INTRODUCTION}

A symmetrical recess in an explosive charge, e.g. in the shape of a cone or a hemisphere (charge cavity), causes the effect of concentration of the explosion energy in a small area. The effect of the directional action of the charge cavity can be intensified by lining the cavity with a layer of a solid in the shape of the cavity [1,2]. This layer is called the shaped charge liner. The pressure of detonation products gradually deforms and drives the liner material, which is divided into two parts, and the masses and velocities of these parts depend, among others, on the design solution of the shaped charge. One part of the liner is called the jet, while the other part is called the slug and is generally not involved in drilling the obstacle. The jest is a strongly deformed stream of material heated to approximately 400 $600^{\circ} \mathrm{C}$, formed from a portion adjacent to the inner surface of the liner. The weight of the jet generated from the conical liner is $10-30 \%$ of the liner weight. The velocity of the jet front reaches the range of $7-10 \mathrm{~km} / \mathrm{s}$ [1]. The parameters of the jet depend on many factors, which include, first of all, the design of the charge (the shape of the liner, the shape of the explosive charge, the method of triggering the explosive, etc.) and the type of the explosive. The type and quality of the liner material, as well as the accuracy of the jet, i.e. its geometrical correctness, also have a significant impact on the penetration performance of the jet [3, 4]. The type and homogeneity of the microstructure of the liner material, as well as its metallurgical purity and internal quality, affect the effectiveness of the shaped charge system. Based on the research and analyses conducted so far, it has been found that a material with a single-phase structure, characterised by good ductility (e.g. elongation in a static tensile test) is favourable [3, 4]. It should be noted, however, that the conditions for the formation of a jet from the liner material are very complex in terms of e.g. strain rate, stress and strain state, temperature and pressure. Therefore, the basic requirement for materials intended for liners is high ductility under conditions of dynamic deformation occurring at a rate of approximately $10000 \mathrm{~s}^{-1}$.

Shaped charges are widely used in the defence and mining industries and are still the subject of works and analyses by many global research centres [5-10]. In particular, research is being carried out on determining the critical characteristics of the material, which are crucial in terms of the penetrating capacity of the jet. Shaped charges with a special design to work in particularly difficult operating conditions are widely used for the perforation of geological survey and mining bores [7-9]. They use, for example, liners drawn from metal or metal alloy powders, including layered liners [10].

The distance of the shaped charge from the obstacle at the time of detonation (standoff) is also an important parameter ensuring the maximisation of the energy transferred to the obstacle by the jet and, as a result, achieving a large penetration depth [11]. In practice, the standoff is often assumed to be in the range of 1 to 3 calibre of shaped charge, but this distance does not always ensure the maximum depth of the hole. It should be noted that this parameter is influenced by, among others, the geometry and type of liner material and the explosive used. The environment in which a given shaped charge is to be used is also important. Therefore, the belief that the distance of the shaped charge from the obstacle should be in the range of 1-3 charge calibres may sometimes be erroneous and not in every case may lead to the maximisation of the en- ergy transferred to the obstacle by the jet [11]. The viability analysis for shaped charges in drilling holes in the mining industry is presented in [12]. It found the potential use of appropriately designed shaped charges equipped with liners made of a material with the desired physical and mechanical properties in order to maximise the drilling effect in terms of the diameter and depth of the drill hole.

The article presents the results of the research carried out under project "Materials with nanocrystalline and amorphous structure for the construction of shaped charge liners for use in the mining industry" (TECHMATSTRATEG) [13-15]. The research concerned iron-based alloys intended for the production of semi-spherical liners dedicated to charges for use in the mining industry. The project is carried out by a consortium consisting of five research units: Łukasiewicz - Institute of Non-Ferrous Metals - Project Leader, Łukasiewicz - Institute of Ferrous Metallurgy, Central Mining Institute, Military University of Technology (WAT), Military Institute of Armament Technology and the Chemical Works "NITRO-CHEM" S.A. company. The main goal of the project is to develop a series of shaped charges of various calibres for use in the mining industry for drilling holes or crushing rocks. As part of the project in the field of charge construction, it is planned to use liners made of alloys based on $\mathrm{Fe}$ and $\mathrm{Cu}$. The works carried out at Łukasiewicz - IMŻ concern the selection of the liner material and the technology of its production on a mass scale, as well as the production of an experimental batch of Fe alloy liners. Based on the available literature data and on the basis of the research experience of the consortium members (WAT), it was assumed that the material for the production of the liners should be characterised by high homogeneity of the microstructure, especially in the area of the liner from which the jet is generated. It was assumed that a material with a single-phase microstructure, with a high degree of purity and good plasticity would have favourable properties from the point of view of the effectiveness of the charge operation. In terms of Fe-based materials, such features are characteristic of alloys with a very low content of carbon and other additive elements, i.e. P, S, $\mathrm{Cu}, \mathrm{Sn}$. The selected material should also have appropriate properties from the point of view of the technology of producing shaped charge liners using cold drawing.

The project proposed the use of high-purity iron-based Fe-Armco alloys, deep-drawn steels, low-carbon steels and modifications of these alloys, e.g. with an increased content of Mn or micro-alloying additives V and Ti. In the first phase of the project, the tested materials were produced in the form of rods for the production of experimental liners using machining. Cold-rolled sheets and strips were prepared for the target production technology of liners using drawing. Attempts were also made to produce liners with the use of additive technologies, in the case of which the feed material was low carbon steel wire with a diameter of $1 \mathrm{~mm}$. These tests were carried out at Łukasiewicz - IMN from the material selected by Łukasiewicz - IMŻ.

The scope of work carried out at Łukasiewicz - IMŻ concerning semi-spherical liners made of Fe alloys included studies of the microstructure and mechanical properties of experimental and target materials developed or selected under the project. In the first phase of the project, liners with a diameter of $50 \mathrm{~mm}$ were produced from heat-treated forged rods using machining at the Military University of Technology. The study of experimental charges containing these liners was aimed at selecting optimal material solutions from the point of view of the effectiveness of 
operation and the availability of the material in terms of serial production. Liners with a diameter of $100 \mathrm{~mm}$ were designed in the next stage of the project. After conducting preliminary tests of drilling holes in concrete blocks, the types of materials were selected, and in the next phase of the project, work is carried out on optimising the geometry of the inserts in terms of diameter, wall thickness, etc.

The article presents the results of research on the microstructure and mechanical properties of Fe alloys from which the experimental liners were made, and then tests of drilling holes in the rock material were carried out. Based on the results of the drilling tests, the final design and material solution for Fe alloy inserts was selected.

\section{TESTING MATERIAL, SCOPE AND METHODOLOGY}

The testing material consisted of experimental Fe-based alloys and low-carbon steels in the form of rods, coldrolled sheets and test sections produced using the additive method of low-carbon steel wire (3D-WAAM printing, i.e. wire arc additive manufacturing). Approx. $50 \times 50 \mathrm{~mm}$ rods were produced using hot forging from laboratory approx. $30 \mathrm{~kg}$ ingots. The ingots were smelted and cast in a vacuum furnace, thus ensuring high metallurgical purity of the alloys. Before making the experimental liners, the semi-finished products in the form of rods were subjected to a heat treatment consisting of austenitising at $920^{\circ} \mathrm{C}$ and free cooling in air or by immersion in water. The aim of the treatment was to homogenise the microstructure in the volume of the rods and to diversify the grain size and mechanical properties. Table 1 shows the chemical compositions of experimental low-carbon steels with microalloying elements for the production of rods from which test liners with a diameter of $50 \mathrm{~mm}$ were made at WAT using machining. The material was diversified in terms of the content of $\mathrm{C}, \mathrm{Mn}$, and $\mathrm{V}$ and Ti microalloying elements. The chemical composition of the experimental steels intended for o liners with a diameter of $100 \mathrm{~mm}$ are presented in Table 2 . Two low-carbon steel grades with a high purity level were selected for the production of a prototype batch of charges.
The study involved planning a production of a test batch of shaped charge liners with a diameter of approx. $100 \mathrm{~mm}$ from low-carbon steel sheets and strips. After the tests on these charges, a decision will be made as to the final diameter of the charge (liner) so that the assumed depth and shape of the crater in the rock material is achieved.

The scope of the research included the characteristics of the microstructure using a light microscope, measurement of mechanical properties in a static tensile test and hardness measurement. The type of microstructure and the uniformity of its distribution in the volume of the material were determined. The yield strength, tensile strength and total elongation were determined in a tensile test. The narrowing was determined for round samples from forged rods. For sheets intended for $100 \mathrm{~mm}$ diameter liners obtained using cold drawing, the anisotropy of the material was additionally determined based on the results of the measurement of mechanical properties.

Table 2. Chemical composition of $A$ and B experimental steel sheets, [weight \%]

Tabela 2. Skład chemiczny blach ze stali eksperymentalnych A i B, [\% masowe]

\begin{tabular}{|l|c|c|c|c|c|c|}
\hline $\begin{array}{c}\text { Steel } \\
\text { identification }\end{array}$ & C & Mn & Si & P & S & Al \\
\hline $\mathrm{A}^{*}$ & 0.08 & 0.40 & - & 0.030 & 0.030 & - \\
\hline $\mathrm{B}^{* \star}$ & 0.02 & 0.20 & 0.006 & 0.006 & 0.008 & 0.045 \\
\hline
\end{tabular}

*) limit contents (allowable maximum)

**) optimum values

\section{TEST RESULTS}

\subsection{RESULTS OF INVESTIGATION OF THE MICROSTRUCTURE AND MECHANICAL PROPERTIES OF THE ROD MATERIAL FOR THE PRODUCTION OF EXPERIMENTAL LINERS}

The results of the examination of the rods' microstructure after the applied heat treatment are presented in Figs. $1-3$. For steel grades with a very low carbon content $<0.01 \%$ (N200 and N201), a single-phase structure with irregular-

Table 1. Required and obtained content of elements in laboratory heats of experimental alloys based on Fe, [weight \%] Tabela 1. Wymagane i uzyskane zawartości pierwiastków w wytopach laboratoryjnych stopów eksperymentalnych na bazie Fe, [\% masowe]

\begin{tabular}{|c|c|c|c|c|c|c|c|c|c|c|c|c|c|c|c|}
\hline $\begin{array}{c}\text { Alloy } \\
\text { identification } \\
\end{array}$ & C & Mn & $\mathbf{S i}$ & $\mathbf{P}$ & $\mathbf{S}$ & $\mathbf{C r}$ & $\mathbf{N i}$ & $\mathrm{Cu}$ & Sn & $\mathbf{v}$ & $\mathbf{T i}$ & Mo & Al & $\begin{array}{c}\mathbf{N}, \\
\text { ppm }\end{array}$ & $\begin{array}{c}\text { o, } \\
\text { ppm }\end{array}$ \\
\hline \multirow{2}{*}{ Requirements } & 0.005 & 0.12 & $\max$ & $\max$ & $\max$ & $\max$ & $\max$ & $\max$ & $\max$ & $\max$ & 0.045 & $\max$ & 0.015 & $\max$ & $\max$ \\
\hline & 0.010 & 0.15 & 0.005 & 0.005 & 0.003 & 0.020 & 0.020 & 0.020 & 0.005 & 0.001 & 0.050 & 0.005 & 0.020 & 50 & 10 \\
\hline N 200 & 0.006 & 0.17 & 0.02 & 0.003 & 0.005 & 0.008 & 0.018 & 0.010 & 0.005 & $<0.005$ & 0.023 & 0.006 & 0.010 & 20 & 12 \\
\hline \multirow{2}{*}{ Requirements } & 0.005 & 0.12 & $\max$ & $\max$ & $\max$ & $\max$ & $\max$ & $\max$ & $\max$ & $\max$ & 0.045 & $\max$ & 0.015 & $\max$ & $\max$ \\
\hline & 0.010 & 0.15 & 0.005 & 0.005 & 0.003 & 0.020 & 0.020 & 0.020 & 0.005 & 0.001 & 0.050 & 0.005 & 0.020 & 50 & 10 \\
\hline N 201 & $<0.006$ & 0.16 & $<0.01$ & 0.004 & 0.004 & 0.008 & 0.018 & 0.009 & 0.005 & $<0.003$ & 0.100 & $<0.005$ & 0.054 & 19 & 60 \\
\hline \multirow{2}{*}{ Requirements } & 0.050 & 1.30 & 0.18 & $\max$ & $\max$ & $\max$ & $\max$ & $\max$ & - & 0.13 & 0.018 & - & 0.018 & - & - \\
\hline & 0.080 & 1.50 & 0.22 & 0.010 & 0.010 & 0.020 & 0.020 & 0.020 & - & 0.17 & 0.022 & - & 0.022 & - & - \\
\hline N 202 & 0.071 & 1.43 & 0.20 & 0.006 & 0.060 & 0.010 & 0.027 & 0.028 & - & 0.16 & 0.033 & - & 0.015 & - & - \\
\hline
\end{tabular}


ly shaped ferrite grains larger than $100 \mu \mathrm{m}$ was obtained. The applied cooling method slightly affected the size and morphology of the microstructure. Particularly for the N201 steel, despite the addition of Ti and high Al content, the grain refinement effect was not achieved. The probable reason is the lack of particles effectively inhibiting the growth of austenite grains due to the insufficient content of $\mathrm{N}$ and $\mathrm{C}$ or the formation of primary TiN, ineffective for inhibiting grain boundaries. For the N202 steel with increased carbon content (approx. 0.07\%), manganese (approx. $1.4 \%$ ) and $\mathrm{Si}$ (approx. $0.20 \%$ ) in relation to N200 and

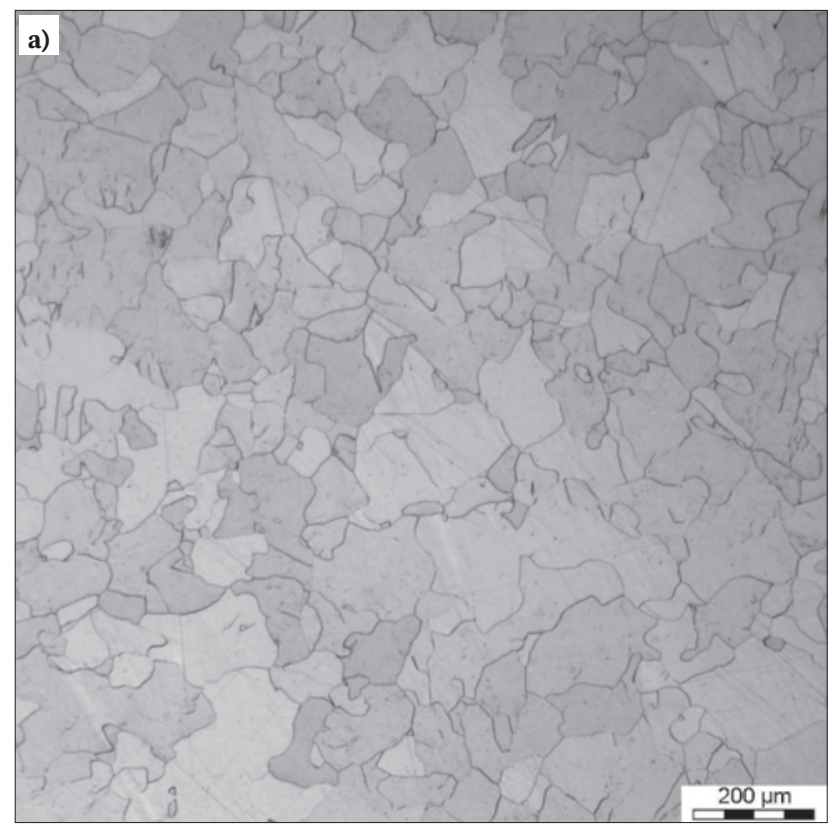

N201, and with a microalloying element of V (0.16\%), a material with a ferritic-pearlitic structure with a very small quantity of pearlite was obtained after cooling in air. The majority of equiaxed ferrite grains was from 10 to $20 \mu \mathrm{m}$. A bainitic structure was obtained after cooling in water for the N202 steel.

The results of hardness measurement are presented in Table 3. For the N200 and N201 grades, a low hardness was obtained, amounting to approx. 90 and $60 \mathrm{HV}$, respectively, slightly differentiated depending on the cooling conditions. In the case of the N202 steel, the hardness after cool-

Fig. 1. Microstructure of $\mathrm{N} 200$ bars after austenitising at $920^{\circ} \mathrm{C}$ and cooling in air (a) and water quenched (b). Longitudinal section, light microscope

Rys. 1. Mikrostruktura prętów ze stopu N 200 po austenityzowaniu w $920^{\circ} \mathrm{C}$ oraz chłodzeniu swobodnym w powietrzu (a) i zanurzeniowo w wodzie (b). Zgład wzdłużny, mikroskop świetlny
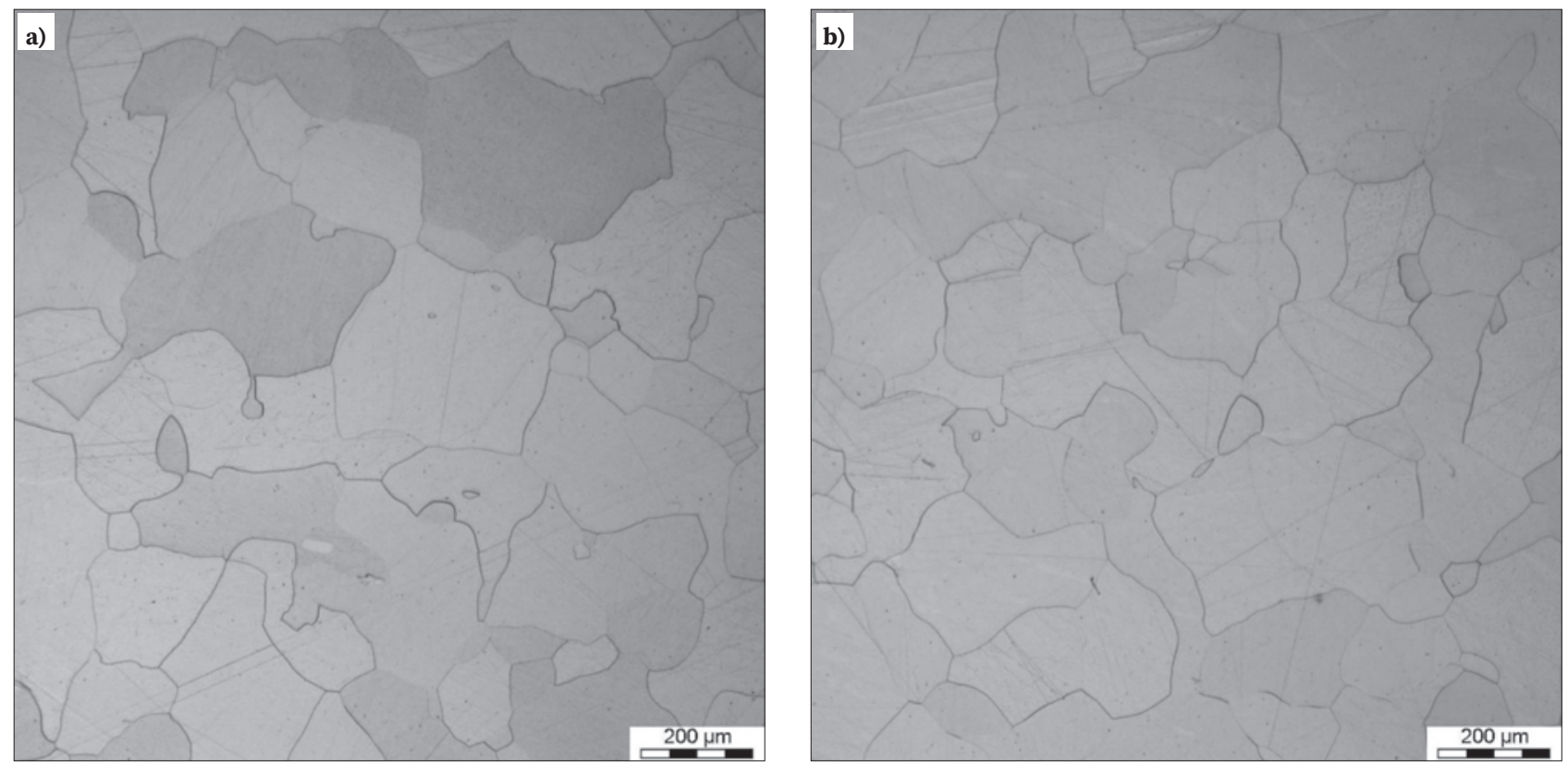

Fig. 2. Microstructure of $\mathrm{N} 201$ bars after austenitising at $920^{\circ} \mathrm{C}$ and cooling in air (a) and water quenched (b). Longitudinal section, light microscope

Rys. 2. Mikrostruktura prętów ze stopu $\mathrm{N} 201$ po austenityzowaniu w $920^{\circ} \mathrm{C}$ oraz chłodzeniu swobodnym w powietrzu (a) i zanurzeniowo w wodzie (b). Zgład wzdłużny, mikroskop świetlny 

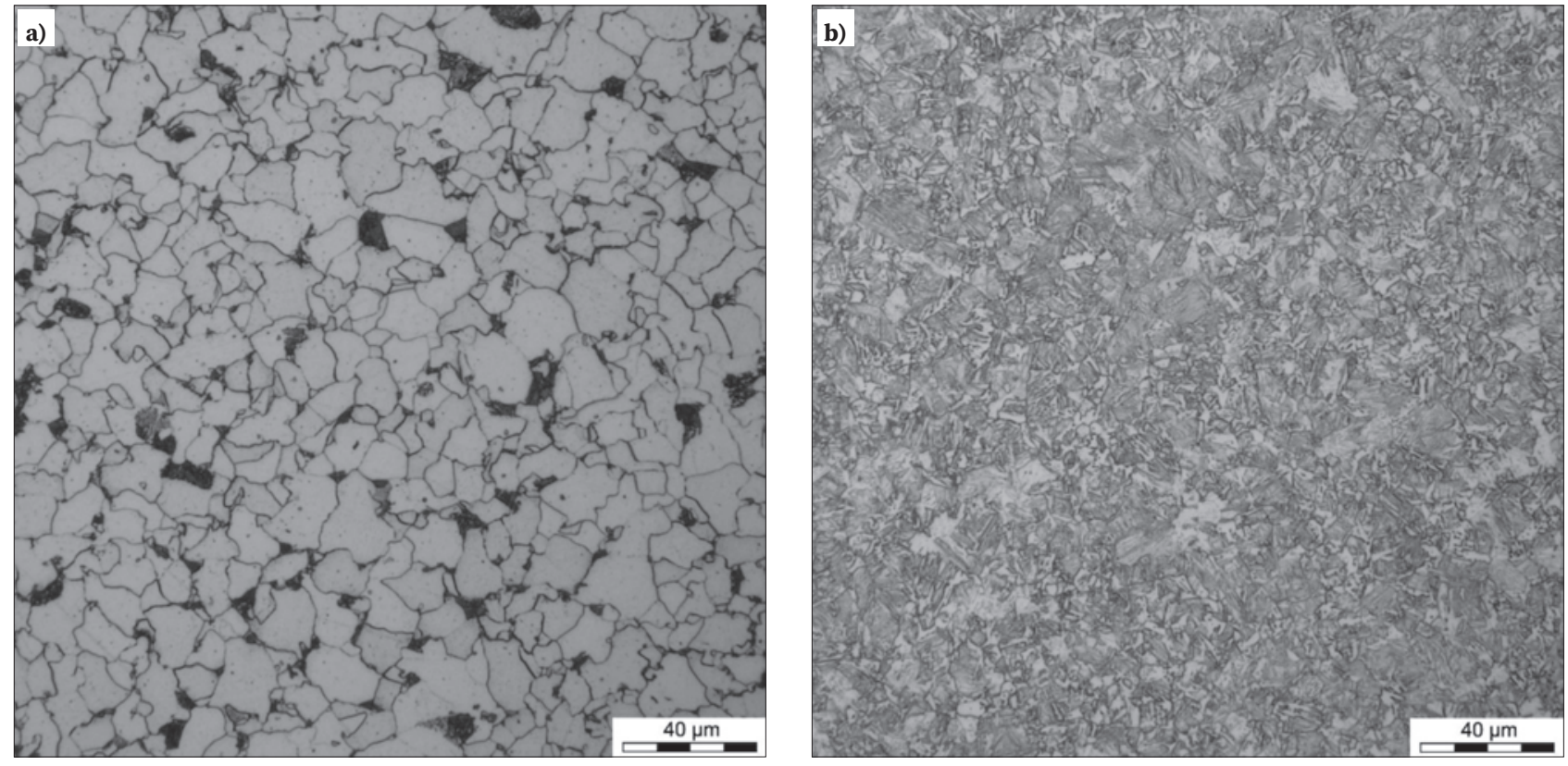

Fig. 3. Microstructure of $\mathrm{N} 202$ bars after austenitising at $920^{\circ} \mathrm{C}$ and cooling in air (a) and water quenched (b). Longitudinal section, light microscope

Rys. 3. Mikrostruktura prętów ze stopu N 202 po austenityzowaniu w $920^{\circ} \mathrm{C}$ oraz chłodzeniu swobodnym w powietrzu (a) i zanurzeniowo w wodzie (b). Zgład wzdłużny, mikroskop świetlny

ing in water was $290 \mathrm{HV}$ and was twice as high as compared to the air-cooled variant (143 HV).

The results of the measurement of mechanical properties in a static tensile test are presented in Table 4. Noteworthy is the N201 heat with a very low yield strength of approx. $100 \mathrm{MPa}$, tensile strength of approx. $270 \mathrm{MPa}$, and a total

Table 3. Results of hardness measurement after thermal treatment Tablica 3. Wyniki pomiarów twardości po obróbce cieplnej

\begin{tabular}{|l|c|}
\hline \multicolumn{1}{|c|}{ Sample identification } & HV hardness \\
\hline N200.920.15air & 85 \\
\hline N200.920.15water & 96 \\
\hline N201.920.15air & 62 \\
\hline N201.920.15water & 64 \\
\hline N202.920.15air & 143 \\
\hline N202.920.15water & 290 \\
\hline
\end{tabular}

Table 4. Mechanical properties of the tested alloys determined in a static tensile test. Round samples with a diameter of $8 \mathrm{~mm}$, average values from three measurements

Tabela 4. Właściwości mechaniczne badanych stopów wyznaczone w statycznej próbie rozciągania. Próbki okraggłe o średnicy 8 mm, wartości średnie z trzech pomiarów

\begin{tabular}{|l|c|c|c|c|}
\hline \multicolumn{1}{|c|}{ Sample identification } & $\begin{array}{c}\mathbf{Y S}_{\mathbf{0 . 2}} \\
{[\mathbf{M P a}]}\end{array}$ & $\begin{array}{c}\boldsymbol{T S} \\
{[\mathbf{M P a}]}\end{array}$ & $\begin{array}{c}\boldsymbol{T E} \\
{[\%]}\end{array}$ & $\begin{array}{c}\boldsymbol{R A} \\
{[\%]}\end{array}$ \\
\hline N200.920.15air & 198 & 295 & 43.6 & 91 \\
\hline N200.920.15water & 204 & 318 & 41.0 & 92 \\
\hline N201.920.15air & 98 & 269 & 48.0 & 92 \\
\hline N201.920.15water & 108 & 269 & 48.4 & 92 \\
\hline N202.920.15air & 357 & 503 & 33.7 & 80 \\
\hline N202.920.15water & 842 & 1067 & 11.9 & 67 \\
\hline
\end{tabular}

elongation in the range of $48 \%$ and a narrowing of $92 \%$. The N200 steel was characterised by high plastic properties (elongation of $41-44 \%$ and narrowing of 91-92\%), and yield strength (approx. $200 \mathrm{MPa}$ ) and tensile strength (approx. $300 \mathrm{MPa}$ ) higher than in the case N201. In the case of the N200 and N201 steels, a slight influence of the cooling method on the mechanical properties in a static tensile test was found. Steel N202, with a higher content, compared to N200 and N201, of carbon, manganese and silicon and with a vanadium microalloying element was characterised by a significantly higher yield strength and tensile strength, as well as lower elongation and narrowing. The mechanical properties of the N202 heat depended on the cooling method applied for the samples. The following parameters were obtained for the variant cooled in water: YS of approx. $840 \mathrm{MPa}$, TS of approx. $1070 \mathrm{MPa}$ and the lowest elongation of approx. $12 \%$ and narrowing of $67 \%$. As a result of cooling in the air, the characteristics of the rods made of this steel were as follows: elongation of approx. 34\%, and $Y S$ $350 \mathrm{MPa}$ and TS of approx. $500 \mathrm{MPa}$. This variant, due to the type of microstructure with a very fine ferrite grains and a small amount of pearlite, as well as a high elongation value, was selected for further research.

Figs. 4 and 5 present examples of tensile curves on the tested low-carbon steels from laboratory heats. The analysis of the research results to date shows that the correct formation of an effective jet should be ensured by steels N200 and N201 due to the single-phase type of microstructure and high elongation values in the static tensile test. However, there are no available results of tests and analyses on the influence of the second phase, the value of the yield and tensile strength, or the strengthening factor on the material's susceptibility to the formation of a jet with the required penetration efficiency. Such data can only be verified on the basis of the results of drilling tests using experimental liner materials with various types of microstructure and mechanical properties. 
a)

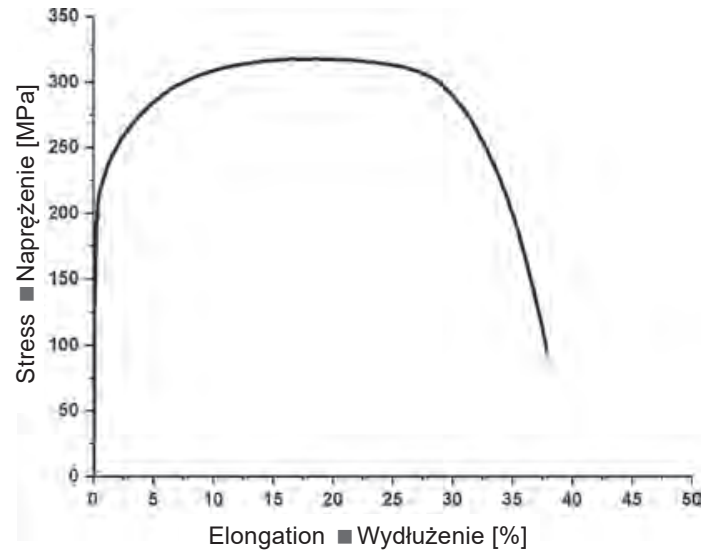

b)

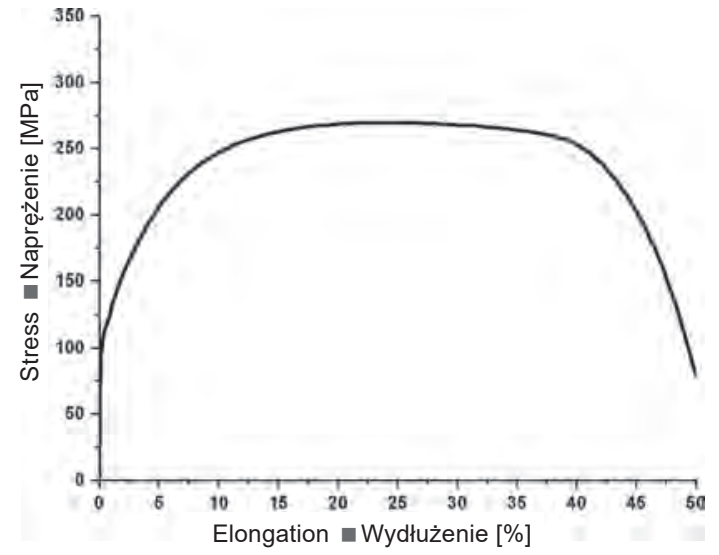

Fig. 4. Tensile curves of alloy $\mathbf{N} 200$ (a) and N 201 (b) after austenitising and cooling in water

Rys. 4. Krzywe rozciagania stopu N 200 (a) i N 201 (b) po austenityzowaniu i chłodzeniu w wodzie

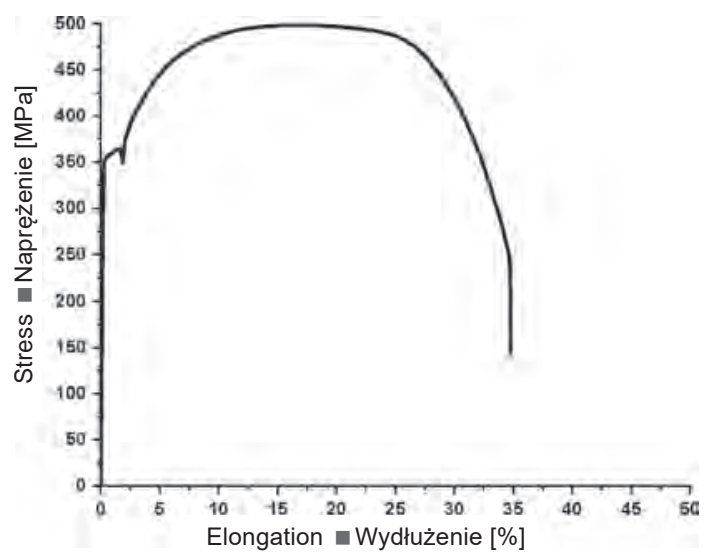

Fig. 5. Tensile curve of alloy $\mathbf{N} 202$ after austenitising and cooling in the air

Rys. 5. Krzywa rozciągania stopu N 202 po austenityzowaniu i chłodzeniu w powietrzu

\subsection{RESULTS OF MICROSTRUCTURE TESTS AND MEASUREMENT OF THE MECHANICAL PROPERTIES OF THE MATERIAL INTENDED FOR THE PRODUCTION OF A TEST BATCH OF LINERS WITH A DIAMETER OF $100 \mathrm{~mm}$}

Two types of steel grades in the form of cold-rolled sheets, marked with symbols A and B, were selected for the production of liners made of Fe-based alloys with a diameter of $100 \mathrm{~mm}$ for the production of a prototype batch of shaped charges. Microstructure tests were carried out on the sheets' longitudinal $\left(0^{\circ}\right)$ and transverse $\left(90^{\circ}\right)$ sections in relation to the rolling direction. The scope of the sheet tests also included static tensile tests in three directions in relation to the rolling direction: parallel $\left(0^{\circ}\right)$, perpendicular $\left(90^{\circ}\right)$ and at an angle of $45^{\circ}$.

Based on the test results of the materials obtained in laboratory conditions, works were continued with the use of cold-rolled steel sheets with a chemical composition similar to vacuum heats N200 and N201. Fig. 6 presents the microstructure of cold-rolled sheets made of steel A. The sheets are characterised by a single-phase ferritic structure with recrystallised grains that are slightly elongated in the rolling direction. The ferrite grains are evenly distributed across the thickness of the sheet, and their size does not exceed approx. $70 \mu \mathrm{m}$. The microstructure of cold-rolled B steel sheets is presented in Fig. 7. The ferrite grains are characterised by an irregular shape and are elongated toward the rolling direction. The structure is homogeneous across the sheet thickness, and the grain size does not exceed approx. $50 \mu \mathrm{m}$.

The results of measurement of the mechanical properties of sheets selected for the production of a prototype batch of $100 \mathrm{~mm}$ diameter liners using cold drawing are summarised in Table 5. Steel A sheets are characterised by high total elongation value of 39-44\%, low yield strength (155-175 MPa) and tensile strength (290-300 MPa). Steel B sheets are also characterised by high plasticity - total elongation of 35-40\%, and slightly higher yield strength (200$220 \mathrm{MPa})$ and tensile strength (320-340 MPa) compared to steel A. Moreover, no clear anisotropy of the properties of the tested steels was found. A slightly higher anisotropy of mechanical properties is characteristic of B steel sheets compared to A steel sheets, but the differences are slight and insignificant from the point of view of the cold drawing process. Fig. 8 presents examples of tensile curves on the tested experimental steels A and B.

Table 5. Mechanical properties of A and B steel sheets. Flat samples, R0, R45 and R90 indicate the longitudinal sample, respectively, taken at an angle of $45^{\circ}$ to the rolling direction, and a transverse sample Tabela 5. Właściwości mechaniczne blach ze stali A i B. Próbki płaskie, R0, R45 i R90 oznaczają odpowiednio próbkę wzdłużną, pobraną pod kątem $45^{\circ}$ do kierunku walcowania i próbkę poprzeczną

\begin{tabular}{|c|c|c|c|c|}
\hline \multicolumn{2}{|c|}{ Sample identification } & YS [MPa] & TS [MPa] & $T E$ [\%] \\
\hline \multirow{9}{*}{ 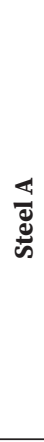 } & A.R0/1 & 171 & 293 & 43.6 \\
\hline & A.R0/2 & 155 & 287 & 43.9 \\
\hline & A. R0/3 & 165 & 292 & 44.4 \\
\hline & A.R45/4 & 175 & 302 & 39.0 \\
\hline & A.R45/5 & 177 & 304 & 39.7 \\
\hline & A.R45/6 & 175 & 304 & 40.6 \\
\hline & A.R90/7 & 174 & 290 & 43.0 \\
\hline & A.R90/8 & 173 & 289 & 43.4 \\
\hline & A.R90/9 & 173 & 290 & 43.2 \\
\hline \multirow{9}{*}{ 禺 } & B.R0/1 & 199 & 327 & 40.1 \\
\hline & B. R0/2 & 203 & 324 & 39.5 \\
\hline & B.R0/3 & 203 & 324 & 39.1 \\
\hline & B.R45/4 & 225 & 342 & 35.0 \\
\hline & B.R45/5 & 227 & 343 & 34.5 \\
\hline & B.R45/6 & 226 & 341 & 34.6 \\
\hline & B.R90/7 & 220 & 327 & 36.2 \\
\hline & B.R90/8 & 220 & 329 & 35.7 \\
\hline & B.R90/9 & 220 & 328 & 36.1 \\
\hline
\end{tabular}



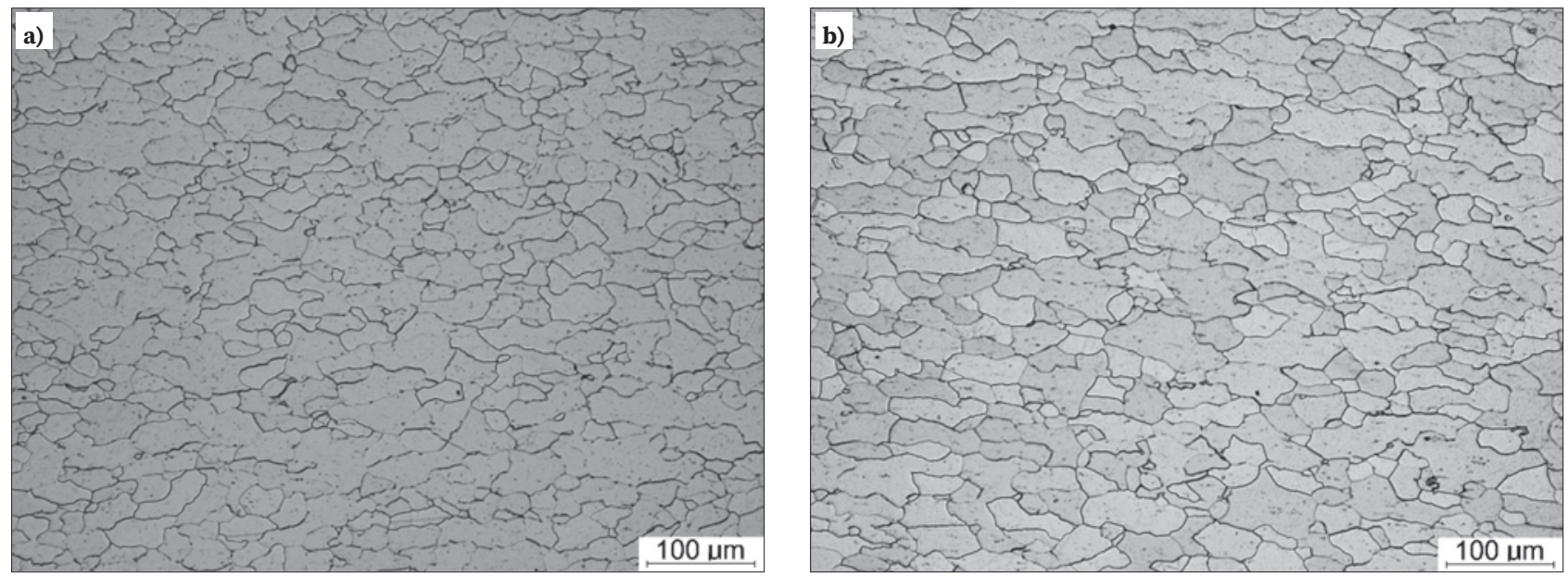

Fig. 6. Microstructure of steel A sheets on longitudinal (a) and transverse (b) section. Light microscope Rys. 6. Mikrostruktura blach ze stali A na zgładzie wzdłużnym (a) i poprzecznym (b). Mikroskop świetlny
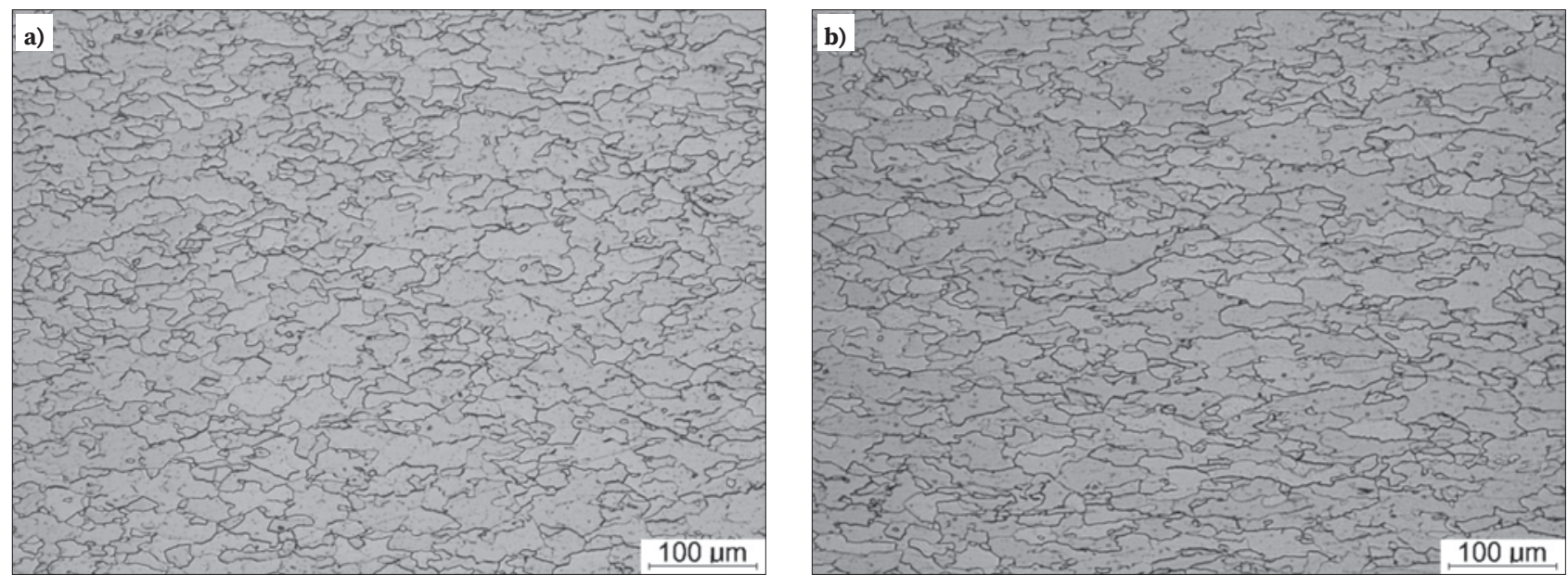

Fig. 7. Microstructure of steel B sheets on longitudinal (a) and transverse (b) section. Light microscope Rys. 7. Mikrostruktura blach ze stali B na zgładzie wzdłużnym (a) i poprzecznym (b). Mikroskop świetlny

a)

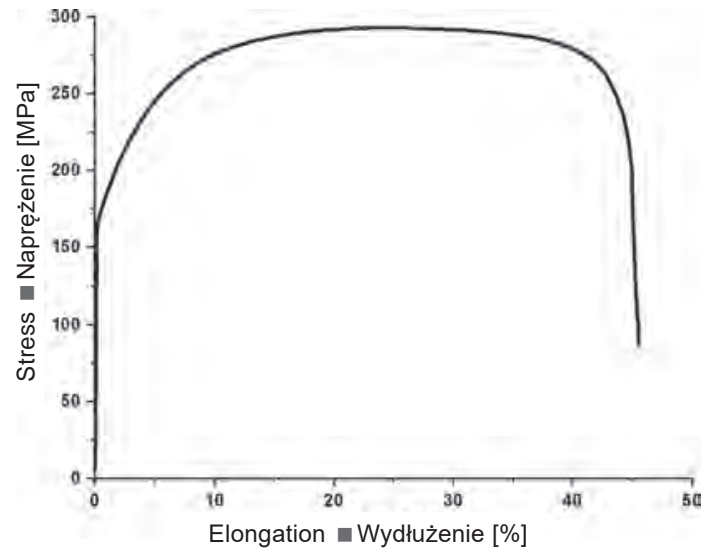

a)

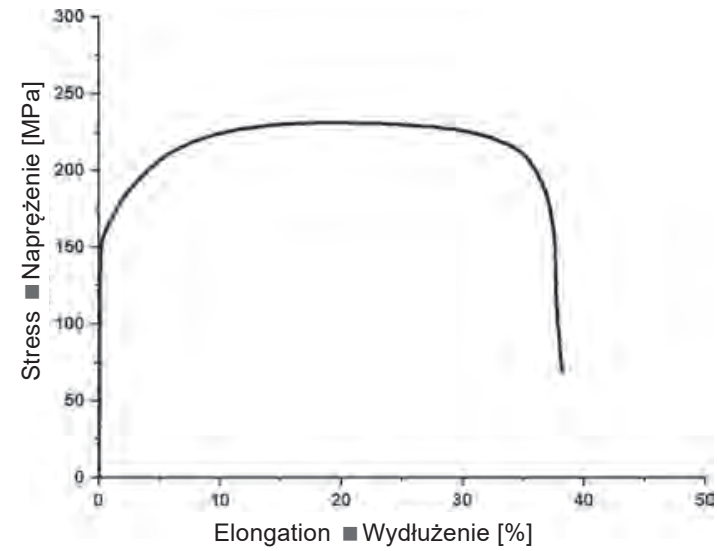

Fig. 8. Tensile curves of A and B steel sheets samples. Longitudinal sample (Table 5 - AR0/1), b) transverse section (Table 5 - BR90/7) Rys. 8. Krzywe rozciągania próbek z blach ze stali A i B. a) próbka wzdłużna (Tab. 5 - AR0/1), b) próbka poprzeczna (Tab. 5 - BR90/7)

\section{RESULTS OF MICROSTRUCTURAL STUDIES OF A TEST SAMPLE PRODUCED WITH THE USE OF 3D-WAAM ADDITIVE TECHNOLOGY}

As part of the preliminary tests, the test material (Fig. 9) was prepared at Łukasiewicz - IMN using the additive tech- nology (3D-WAAM printing), for which the feed was a wire with a diameter of $1.0 \mathrm{~mm}$ made of unalloyed low-carbon steel. The macro- and microstructure studies were carried out on specimens that were longitudinal and transverse to the direction of growth of individual layers during the manufacturing process. At the current stage of the research, no 
a)

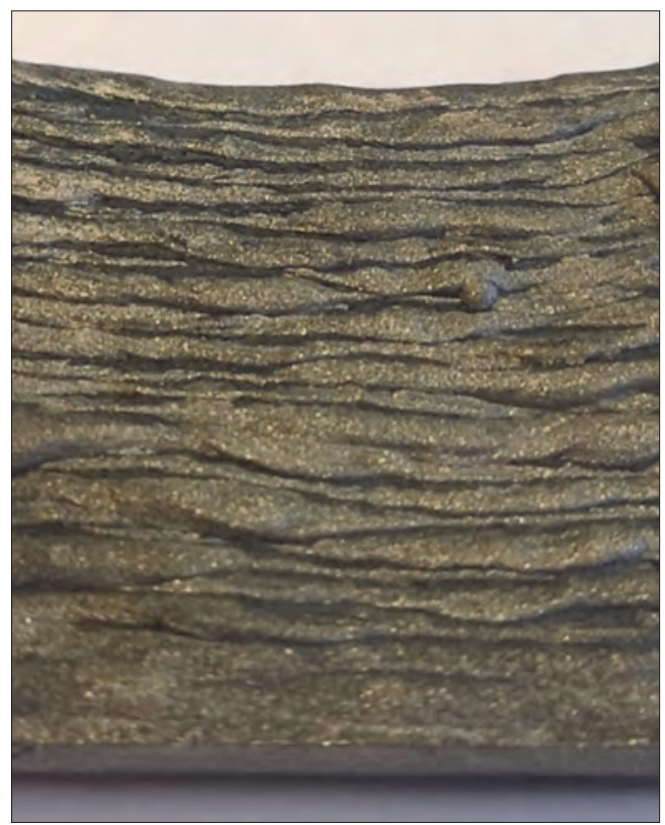

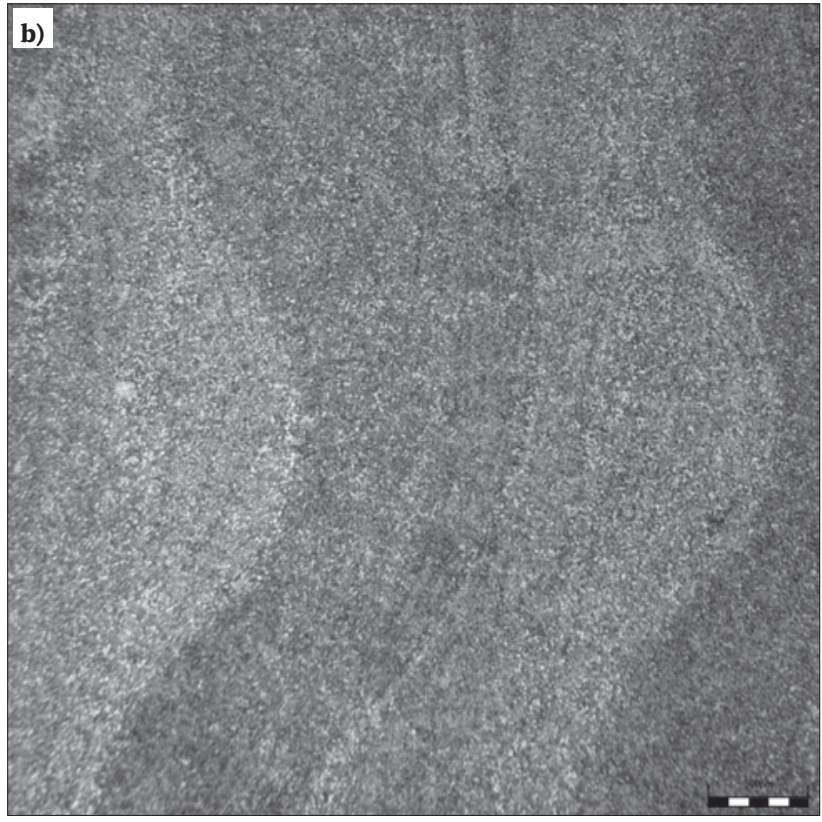

Fig. 9. Photograph (a) and macrostructure (b) of the material produced with the use of additive technology from non-alloy low-carbon steel wire with a diameter of $1 \mathrm{~mm}$

Rys. 9. Fotografia (a) oraz makrostruktura (b) materiału wytworzonego z zastosowaniem technologii przyrostowej z drutu ze stali niskowęglowej niestopowej o średnicy 1 mm
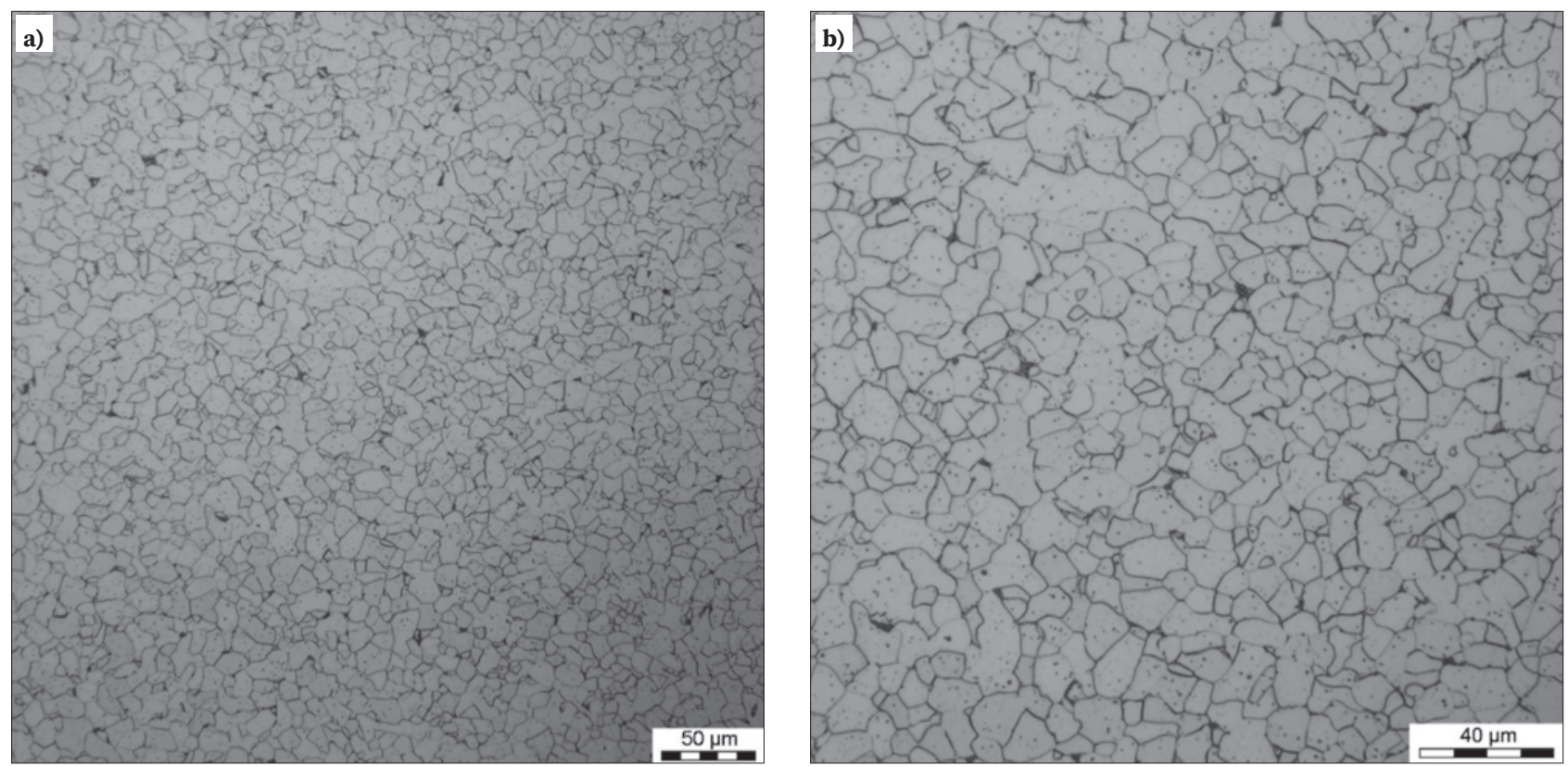

Fig. 10. Microstructure of sample produced with the use of additive technology (WAAM) from a wire with a diameter of 1 mm made from unalloyed low-carbon steel. Longitudinal section, light microscope

Rys. 10. Mikrostruktura próbki wytworzonej z zastosowaniem technologii przyrostowej (WAAM) z drutu o średnicy 1 mm ze stali niskowęglowej niestopowej. Przekrój wzdłużny, mikroskop świetlny

tests have been carried out to improve the surface quality. The main goal was to test the material with regard to homogeneity, internal defects (porosity) and the type of microstructure.

Based on the results of macrostructure tests, no voids or porosity were found on the tested sample's cross-sections (Fig. 9b). The microstructure of the material, regardless of the tested cross-section, was equiaxed ferrite with a grain size of approx. $10 \mu \mathrm{m}$ with a small amount of pearlite (Fig. 10). Ferrite grains in the 3D-WAAM printing process were recrystallised and refined. The results of the analysis showed that the structure of the material immediately after the manufacturing process using the wire additive method is uniform, recrystallised and isotropic. This type of microstructure is favourable from the point of view of the formation of the jet. Research on Fe-based materials for the production of experimental liners using the additive method will be continued due to the potential possibility of shaping a homogeneous and fine-grained microstructure in the entire volume of the liner material. 


\section{PRELIMINARY TESTS OF SHAPED CHARGES CONTAINING LINERS MADE OF IRON-BASED ALLOYS}

For preliminary tests, charges were prepared using liners made of experimental Fe alloys. An explosive based on TNT and hexogen (composition B) was used for the elaboration of the charges. Charge covers and other parts that make up the structure of the experimental charges were made using $3 \mathrm{D}$ printing from anti-electrostatic material with the use of printing systems provided by WAT's Institute of Armament Technology. The scope of preliminary tests of the new range included:

- assessment of the correctness of the formation of a coherent jet from the selected liner materials,

- evaluation of the effectiveness of the experimental shaped charge for drilling a hole in a concrete block.

In order to assess the correctness of the formation of the jet, firing tests were carried out at the WITU test site with the use of charges containing a semispherical liner made of an alloy based on Fe. An exemplary crater inlet made caused a shaped charge system containing a semispherical liner is shown in Figure 11. The tests showed that the use of an iron liner allowed for the correct formation of a coherent jet.

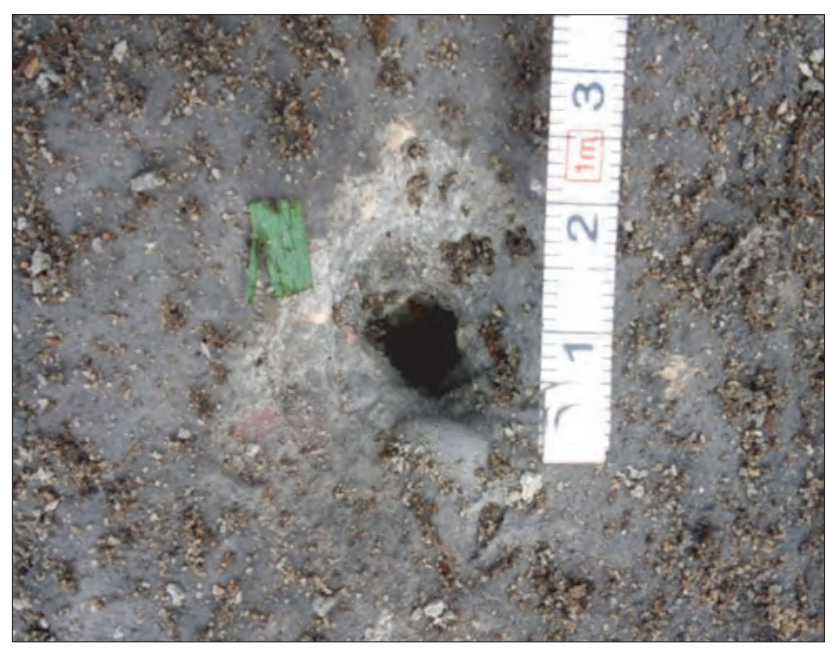

Fig. 11. Photograph of inlet in a concrete slab after firing with a shaped charge containing a semi-spherical liner made of an ironbased alloy

Rys. 11. Fotografia otworu wlotowego w płycie betonowej po strzale ładunkiem kumulacyjnym zawierającym półsferyczną wkładkę ze stopu na bazie zelaza

Firing tests on concrete blocks were carried out at the Experimental Mine Barbara in order to quantify the depth of drilling with the experimental charges. The scope of the studies consisted of firing tests at cylindrical concrete blocks using projectiles containing liners made of Fe-based alloys. The purpose of the research was to determine the effectiveness of charges for drilling holes in a material imitating natural rock (concrete with a compressive strength of approx. $30 \mathrm{MPa}$ ) and to test the occurrence of the phenomenon of creating an open stream of fire. The front views of shaped charge systems containing semi-spherical liners made of Fe-based alloys are shown in Figure 12. The assembly of the charges consisted of placing the liner in the cover with a retaining ring and the use of epoxy glue. Then the cover, closed on one side, with a shaped charge
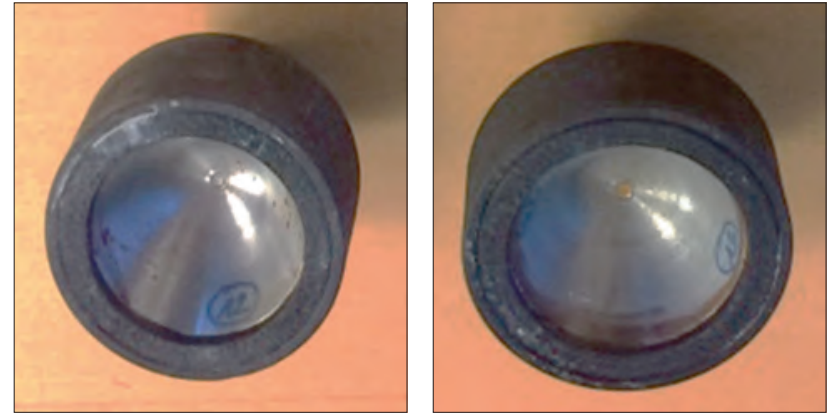

Fig. 12. Shaped charge systems with iron alloy liners

Rys. 12. Układy kumulacyjne $\mathrm{z}$ wkładkami wykonanymi ze stopów zelaza

liner was filled with a cast explosive, i.e. composition B. The shaped charges were detonated using ERG detonators via $\phi 23.5 \mathrm{~mm}$ and $15 \mathrm{~mm}$ high boosters. The charges were placed at a distance of 3 times the calibre, i.e. $150 \mathrm{~mm}$, from the front of the concrete block. Two types of shaped charges were used, differing in the weight of the explosive, i.e. $100 \mathrm{~g}$ and $200 \mathrm{~g}$. As a result of the detonation of the charges, conical holes were formed in the concrete block, the depth of which was measured using rods with a diameter of 2, 6, 12 and $15 \mathrm{~mm}$. The results of crater geometry measurement are presented in Table 6. An exemplary view of an inlet in a concrete block is shown in Figure 13.

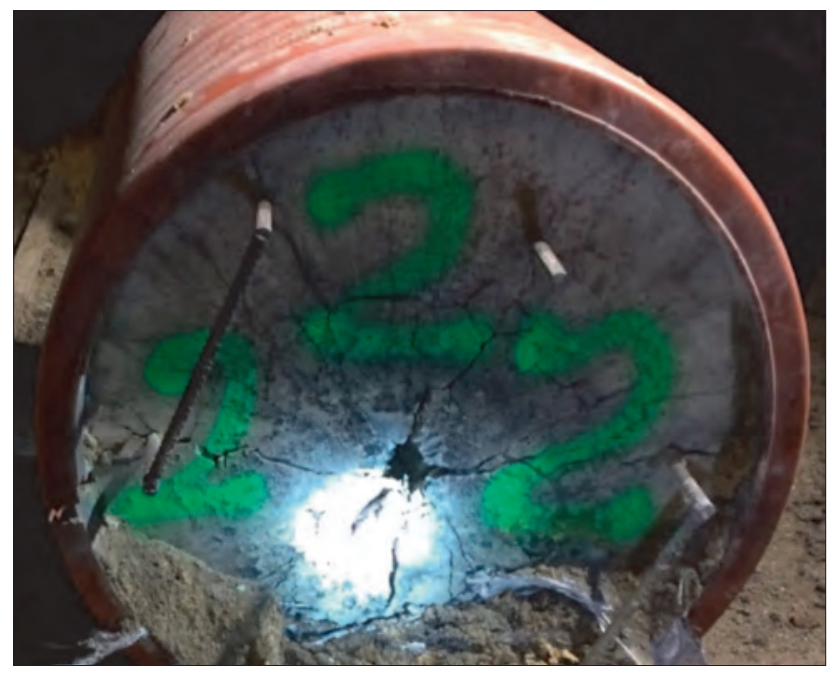

Fig. 13. Photograph of a concrete block inlet after firing a shaped charge containing an iron alloy liner with a diameter of $50 \mathrm{~mm}$

Rys. 13. Fotografia otworu wlotowego $w$ bloku betonowym po ostrzale ładunkiem zawierającym wkładkę o średnicy $50 \mathrm{~mm}$ wykonaną ze stopu żelaza

For a weight of explosive of $200 \mathrm{~g}$ with liners made of experimental alloys N200, N201 and N202, similar values of hole depths were obtained, amounting to an average of $100 \mathrm{~mm}$ for a $15 \mathrm{~mm}$ hole diameter and from 160 to 190 $\mathrm{mm}$ for a $6 \mathrm{~mm}$ diameter. For material B, a depth of 130 $\mathrm{mm}$ was obtained for a hole diameter of $12 \mathrm{~mm}$; 130-140 $\mathrm{mm}$ for a diameter of $6 \mathrm{~mm}$ and $195 \mathrm{~mm}$ for a hole diameter of $2 \mathrm{~mm}$. A test with a $100 \mathrm{~g}$ explosive shaped charge showed that the crater depth was $150 \mathrm{~mm}$ (for a $2 \mathrm{~mm}$ diameter hole) and is smaller - as predicted - compared to the depth of a $200 \mathrm{~g}$ explosive crater by about $20 \%$. In turn, the depth of the crater with a diameter of not less than 12 
$\mathrm{mm}$ was $130 \mathrm{~mm}$ and it was comparable to the depth of a hole obtained using an analogous shaped charge containing a $200 \mathrm{~g}$ explosive.

Initial results of drilling with the use of shaped charges indicate comparable effectiveness of the tested materials of liners. Slightly larger volumes of drilled holes were obtained for the experimental materials of the N200-201 series compared to alloy B. Based on the obtained test results, materials $A$ and $B$ were selected for producing $100 \mathrm{~mm}$ diameter liners. These materials are similar to laboratory heets N200 and N201, which are characterised by a single-phase microstructure and a high value of elongation in a static tensile test.

Table 6. Crater depths in concrete blocks created by firing with shaped charges containing half-spherical liners with a diameter of $50 \mathrm{~mm}$ made of iron-based alloys. The distance from the charge to the front surface of the concrete block was $150 \mathrm{~mm}$

Tabela 6. Głębokości kraterów w blokach betonowych powstałych w wyniku ostrzału za pomocą ładunków kumulacyjnych zawierających wkładki półsferyczne o średnicy $50 \mathrm{~mm}$, wykonane ze stopów na bazie żelaza. Odległość ładunku od powierzchni czołowej bloku betonowego wynosiła $150 \mathrm{~mm}$

\begin{tabular}{|l|c|c|}
\hline \multicolumn{1}{|c|}{$\begin{array}{c}\text { Type of liner } \\
\text { material }\end{array}$} & $\begin{array}{c}\text { Weight } \\
\text { of explosive } \\
\text { [g] }\end{array}$ & $\begin{array}{c}\text { Hole depth for individual } \\
\text { diameters } \mathbf{\Phi} \\
\text { [mm] }\end{array}$ \\
\hline $\begin{array}{l}\text { Experimental alloy } \\
\text { Fe - ID N200 }\end{array}$ & 200 & $\Phi 6-190$ \\
\hline Experimental alloy & 200 & $\Phi 15-105$ \\
Fe - ID N201 & 200 & $\Phi 6-163$ \\
\hline Experimental alloy & & $\Phi 15-111$ \\
Fe - ID N202 & 200 & $\Phi 6-172$ \\
\hline & & $\Phi 2-195$ \\
Steel B & \multirow{2}{*}{100} & $\Phi 12-130$ \\
\hline & & $\Phi 2-150$ \\
\hline Steel B & & $\Phi 6-140$ \\
& & \\
\hline
\end{tabular}

\section{SUMMARY}

The article presents the results of investigation of the microstructure and mechanical properties of Fe-based materials intended for the production of shaped charge liners with a diameter of $50 \mathrm{~mm}$, made of rods obtained using machining, and with a diameter of $100 \mathrm{~mm}$ made of sheets using cold drawing. Microstructure examination was also carried out on a test specimen obtained using the additive method (3D-WAAM printing), made of low-carbon unalloyed steel wire.
The rods for the production of liners with a diameter of $50 \mathrm{~mm}$ were made of three experimental steel grades with various contents of $\mathrm{C}, \mathrm{Mn}, \mathrm{Si}$ and $\mathrm{V}$ and Ti microalloying elements. The microstructure of materials with a very low carbon content was ferrite with grain sizes ranging from several dozen to over $100 \mu \mathrm{m}$. The material was characterised by very good plasticity defined by the total elongation in the range of $41-48 \%$ with YS and TS values of $100-200$ $\mathrm{MPa}$ and 270-320 MPa, respectively. For the low-carbon steel with a $\mathrm{V}$ microalloying element, a ferrite grain structure with an average mean linear intercept of approx. $10 \mu \mathrm{m}$ with a very low pearlite content was obtained. Air cooling of rods made of this steel grade after austenitisation ensures high elongation values above $30 \%$, as well as YS of approx. $350 \mathrm{MPa}$ and TS of approx. $500 \mathrm{MPa}$.

Based on the results on the examination of the laboratory material of the N200 and N201 series, experimental steels marked A and B were selected for further research. Sheets made of the selected steels will be used to manufacture liners with a diameter of $100 \mathrm{~mm}$. These steels are characterised by a single-phase ferritic structure of different morphology and grain size in the mean linear intercept range from 30 to $70 \mu \mathrm{m}$. The mechanical properties of A and B steel sheets are characterised by the high value of total elongation of $35-44 \%$ and a low value of yield strength (155-220 MPa) and tensile strength in the range of 290-340 MPa.

The microstructure of the test sample produced using the additive method in the state immediately after printing and free cooling is characterised by an equiaxed ferrite grain of approx. $10 \mu \mathrm{m}$ with a very small amount of pearlite. This method of producing the liner material due to the type of microstructure created without additional heat and plastic treatment will be subjected to further tests in order to obtain semi-finished products for the production of test liners.

The tests carried out at Experimental Mine Barbara with the use of shaped charges with iron-based semi-spherical liners with a diameter of $50 \mathrm{~mm}$ allowed for the quantification of the effectiveness of charges based on the measurement of the crater depth. As a result of using a charge with a semi-spherical liner made of the selected Fe alloy (B) for the explosive's weight of $200 \mathrm{~g}$, a hole with a diameter of $12 \mathrm{~mm}$ and a depth of about $130 \mathrm{~mm}$ was obtained, which is comparable to that obtained for a copper liner.

The article presents the results of the research carried out under Techmatstrateg project No. 1/349156/13/NCBR/2017 "Materials with nanocrystalline and amorphous structure for the construction of shaped charge liners for use in the mining industry TECHMATSTRATEG1315". 


\section{REFERENCES}

[1] W.P. Walters, J.A. Zukas. Fundamentals of shaped charges. New York: A. Wiley-Interscience Publication, 1989.

[2] D.C. Pack, W.M. Evans. Penetration by high-velocity (Munroe) jets: I. Proceedings of the Physical Society, B, 1951, 64 (4), p. 298.

[3] J. Janiszewski, E. Włodarczyk. Rola materiału wkładki w formowaniu strumienia kumulacyjnego (synteza danych literaturowych). Biuletyn WAT, 2002, 51 (3), pp. 41-64.

[4] H.N. Kalia. Penetration in granite by shaped charge liners of various metals. Doctoral Dissertations, 1970, No. 2038.

[5] H. Nowak, D. Smoleński. Ładunki kumulacyjne w wojsku, górnictwie i przemyśle. Warszawa: Wydawnictwo MON, 1974.

[6] B. Bourne, K.G. Cowan, J.P. Curtis. Shaped charge warheads containing low melt energy metal liners. In: Proc. 19th Int. Symp. Ballistics. Switzerland, 2001, pp. 583-589.

[7] Z. Wilk, B. Zygmunt. Zastosowanie ładunków kumulacyjnych do perforacji odwiertów geologicznych. Biuletyn WAT, 2007, 56, (1), pp. 245-258.

[8] C.J. Poole, J.R. Ockendon, J.P. Curtis. Gas leakage from fragmentation warheads. In: Proc. 20th Int. Symp. Ballistics, Florida, 2002 pp. 113-117.

[9] T. Elshenawy, Q.M. Li. Influences of target strength and confinement on the penetration depth of an oil well perforator. International Journal of Impact Engineering, 2013, 54, pp. 130-137.
[10] Z. Wilk, B. Zygmunt, A. Jackowski. Koncepcja technologii wytwarzania wkładek proszkowych do ładunków kumulacyjnych stosowanych w perforacji odwiertów geologicznych. Biuletyn WAT, 2007, 56 (2), pp. 109-122.

[11] A. Wojewódka, T. Witkowski. Metodyka modelowania procesu formowania strumienia kumulacyjnego wydłużonych ładunków materiałów wybuchowych. Chemik, 2011, 65, 1, pp. 28-35.

[12] W. Burian, M. Magier, M. Rotkegel, J. Sobala, J. Szymała, A. Żak. Badania możliwości otworowania $\mathrm{z}$ wykorzystaniem ładunków kumulacyjnych. Przegląd Górniczy, 2016, 72 (7), pp. 20-25.

[13] A. Żak, J. Marcisz et al. Materiały o strukturze nanokrystalicznej i amorficznej do konstrukcji wkładek kumulacyjnych do zastosowania w przemyśle wydobywczym. Łukasiewicz - IMŻ Research Project Report No. PI 0010 02-02 i PI 0010 02-04, December 2018. [unpublished].

[14] J. Marcisz, A. Żak, T. Tomczak et al. Materiały o strukturze nanokrystalicznej i amorficznej do konstrukcji wkładek kumulacyjnych do zastosowania w przemyśle wydobywczym. Łukasiewicz - IMŻ Research Project Report No. PI 0010 03-02 part 1, December 2019. [unpublished].

[15] J. Marcisz, J. Stępień, T. Tomczak. Materiały o strukturze nanokrystalicznej i amorficznej do konstrukcji wkładek kumulacyjnych do zastosowania w przemyśle wydobywczym. Łukasiewicz - IMŻ Research Project Report No. PI 0010 03-02 part 2, December 2020. [unpublished]. 